\title{
Analysis and Characterization of Wastewater Nitrogen Components for using in Wastewater Modeling and Simulation
}

\author{
Ragaa El Sheikh $^{1}$, Ayman A. Gouda ${ }^{1}$, Atef Salem, Ibrahim Hendy ${ }^{2}$ \\ ${ }^{1}$ Department of Chemistry, Faculty of Science, Zagazig University, Zagazig, 44519, Egypt. \\ ${ }^{2}$ Department of Environmental Engeneering, Faculty of Engeneering, Zagazig University, Zagazig, \\ Egypt. \\ aymangouda77@gmail.com
}

\begin{abstract}
The wastewater characterization, modeling and simulation study is the base of the design wastewater treatment plants (WWTPs). So that this paper investigate analysis and characterization of wastewater nitrogen components for using in wastewater modeling and simulation. The analysis was taken for raw wastewater, and settled wastewater. The wastewater samples source for the present study was a preliminary treated wastewater from Al Qenayat wastewater treatment plant, Zagazig, Egypt. Distillation apparatus used to measure ammonia nitrogen method and total kjeldahl nitrogen (TKN) method. Raw wastewater, ammonia nitrogen percent was $73.5 \%$ from TKN, soluble organic nitrogen biologically degradable, $S_{N D}$ percent was $8.3 \%$ from TKN, soluble organic nitrogen biologically undegradable, $S_{N I}$ percent was $3.4 \%$ from TKN, particulate organic nitrogen biologically degradable, $X_{N D}$ percent was $6.2 \%$ from TKN, particulate organic nitrogen biologically undegradable and XNI percent was 3.4\% from TKN. Settled wastewater, ammonia nitrogen percent was $77.2 \%$ from TKN, soluble organic nitrogen biologically degradable, $S_{N D}$ percent was $8.5 \%$ from TKN, soluble organic nitrogen biologically undegradable, $S_{N I}$ percent was $3.8 \%$ from TKN, particulate organic nitrogen biologically degradable, $X_{N D}$ percent was $6.4 \%$ from TKN, particulate organic nitrogen biologically undegradable and $X_{N I}$ percent was $4.1 \%$ from TKN.
\end{abstract}

Keywords: Nitrogen components, TKN, ammonia, Wastewater Nitrogen, Simulation, Wastewater modeling.

\section{INTRODUCTION}

Since it seemed wastewater treatment, the wastewater characterization was important for the wastewater treatment plants design, operation and optimization. The wastewater characterization development the analysis methods [1]. The wastewater modeling and simulation study is the base of the design of activated sludge wastewater treatment plants WWTPs. The level of model calibration is quite low when wastewater samples are not available for characterization [2]. In terms of nitrogen compounds, it was very important in management of raw wastewater and this was due to the effected of the nitrogenous material on the environment, the raw wastewater nitrogen forms were ammonia, organic nitrogen forms and very small quantities of nitrite and nitrate forms [3]. The nitrogenous compounds, were in the form of organic nitrogen and inorganic total ammonia nitrogen $\left(\mathrm{NH}_{3}+\mathrm{NH}_{4}-\right.$ $\mathrm{N})$, represented together by the TKN, and the oxidized nitrogen compounds, such as nitrate $\left(\mathrm{NO}_{3}-\mathrm{N}\right)$ and nitrite $\left(\mathrm{NO}_{2}-\mathrm{N}\right)$ nitrogen. The oxidized nitrogen compounds are usually present in low quantities in raw and settled sewage, the inorganic total ammonia nitrogen remain in solution as ammonium nitrogen $\left(\mathrm{NH}_{4}-\mathrm{N}\right)$ and ammonia $\left(\mathrm{NH}_{3}-\mathrm{N}\right)$, and this was depended on the $\mathrm{pH}$, with $\mathrm{NH}_{4}-\mathrm{N}$ being predominant at conditions with a $\mathrm{pH}$ below 7.0 [4]. The organically bound nitrogen (e.g. protein, urea) is difficult to fractionate into biodegradable and unbiodegradable soluble and particulate fractions [5].

Ammonia nitrogen result from the wastewater influent urea, and the inorganic nitrogen have been removed about 80 to 95 percent by nitrification and denitrification, but the organic nitrogen removed much less efficient [6]. Total ammonia determined by Nessler's method, this method require to use the toxic mercury compound. So Berthelot method was more sensitive than Nessler's method [7]. The most important influent nitrogen components in ASM1., which are used as component variables in activated sludge models, are shown in Fig. 1. [8] 


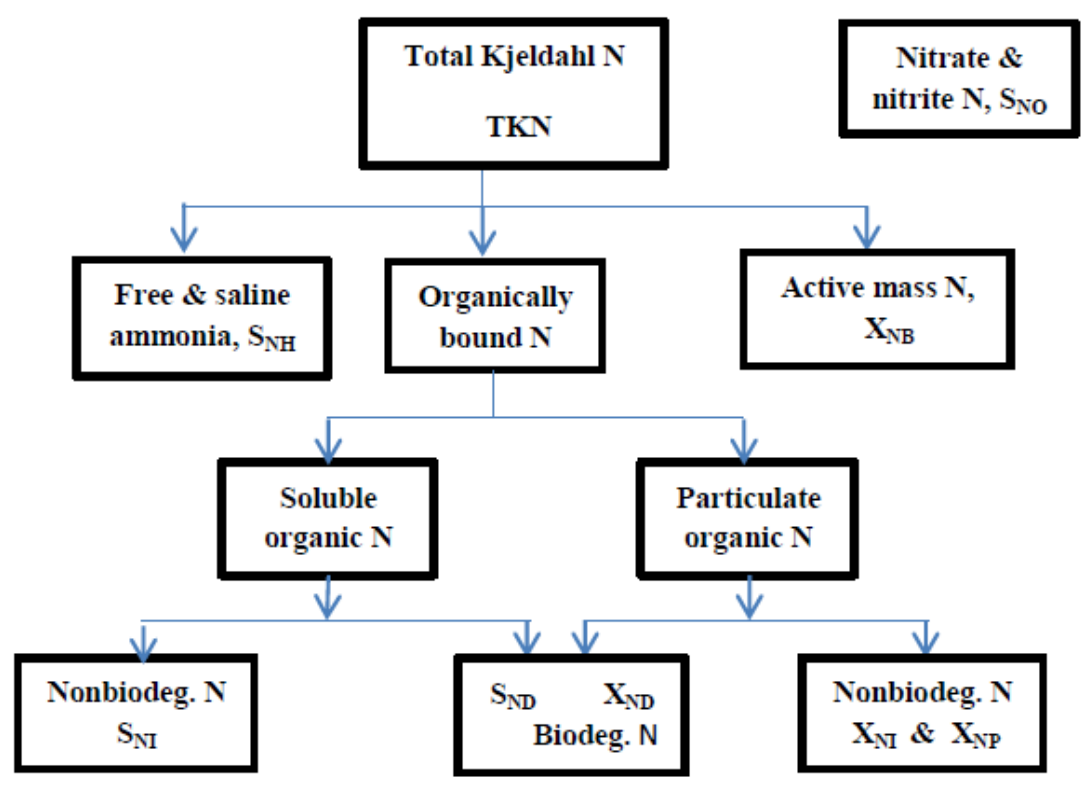

Figure1. Wastwater characterization for nitrogen components in ASMI

The nitrogenous material in the wastewater was divided as shown in figure 1. Based on measurements of total Kjeldahl nitrogen (TKN), the nitrogen was divided into ammonia nitrogen $\left(\mathrm{S}_{\mathrm{NH}}\right)$, organically bound nitrogen and active mass nitrogen, that was a fraction of the biomass which was assumed to be nitrogen. Similar to the division of the organic material, the organically bound nitrogen was divided into soluble and particulate fractions, which in turn may be biodegradable or non-biodegradable. It should be noted that only particulate biodegradable organic nitrogen $\left(\mathrm{X}_{\mathrm{ND}}\right)$ and soluble biodegradable organic nitrogen $\left(\mathrm{S}_{\mathrm{ND}}\right)$ were explicitly included in the model. The active mass nitrogen $\left(\mathrm{X}_{\mathrm{NB}}\right)$ was included in the model only in the sense that decay of biomass will lead to a production of particulate biodegradable organic nitrogen. Organic nitrogen associated with the inert organic particulate products $\left(\mathrm{X}_{\mathrm{NP}}\right)$ and the inert organic particulate matter $\left(\mathrm{X}_{\mathrm{NI}}\right)$ can easily be calculated, although not described in the model matrix. Finally, the nitrification of ammonia to nitrate nitrogen $\left(\mathrm{S}_{\mathrm{NO}}\right)$ was considered as a single step process [9]. According to the ASM1 model, the fractional composition of TKN can be described as follows:

$$
\mathrm{TKN}=\mathrm{S}_{\mathrm{NH}}+\mathrm{S}_{\mathrm{ND}}+\mathrm{S}_{\mathrm{NI}}+\mathrm{X}_{\mathrm{ND}}+\mathrm{X}_{\mathrm{NI}}
$$

The concentrations of different nitrogen compounds in the domestic wastewater inflow varied with variations of seasons, weather, residents etc., [10].

Concentration and presence of interferences are the two major factors that influence selection of the method to determine ammonia. In general, direct manual determination of low concentrations of ammonia is confined to drinking waters, clean surface or groundwater, and good-quality nitrified wastewater effluent. In other instances, and where interferences are present or greater precision is necessary, a preliminary distillation step is required. The kjeldahl methods (Macro-Kjeldahl Method and Semi-Micro-Kjeldahl Method) determine nitrogen in the trinegative state. They fail to account for nitrogen in the form of azide, azine, azo, hydrazone, nitrate, nitrite, nitrile, nitro, nitroso, oxime, and semi-carbazone. "Kjeldahl nitrogen" is the sum of organic nitrogen and ammonia nitrogen [11].

The proportions of nitrogen compounds undergo changes during the inflow of combined wastewater to the WWTP. The results of analyses of the TKN fractions obtained for dry weather raw wastewater are presented in Table 1 [12].

Table1. Percentage contribution of particular fractions in TKN of raw wastewater

\begin{tabular}{|l|l|l|l|l|l|l|}
\hline TKN fraction & $\mathrm{S}_{\mathrm{NH}}$ & $\mathrm{S}_{\mathrm{ND}}$ & $\mathrm{S}_{\mathrm{NI}}$ & $\mathrm{X}_{\mathrm{NI}}$ & $\mathrm{X}_{\mathrm{ND}}$ & Reference \\
\hline & 66.5 & 5.8 & 8.4 & 6.8 & 12.5 & {$[12]$} \\
\hline & 60 & 10 & $*$ & $*$ & 25 & {$[13]$} \\
\hline & 75 & 6 & $*$ & $*$ & 6 & {$[14]$} \\
\hline & 73 & 9 & - & - & 12 & {$[15]$} \\
\hline
\end{tabular}

$* X_{N I}+S_{N I}-$ up to $5 \%$ according to [13], up to $13 \%$ according to [14]. 


\section{Ragaa El Sheikh et al.}

The aim of the present work is to investigate analysis and characterization of wastewater nitrogen components for using in wastewater modeling and simulation.

\section{EXPERIMENTAL}

\subsection{Apparatus}

The temperature was measured utilizing thermocouple thermometer; of type $\mathrm{T}$, with measuring range from $0^{\circ} \mathrm{C}$ to $100^{\circ} \mathrm{C}$ and accuracy of $\pm 0.1^{\circ} \mathrm{C}$. WTW inoLap pH-meter level 2 instrument (USA) equipped with a combined glass-calomel electrode was used for checking the $\mathrm{pH}$ of the samples, with measuring range from 0 to 14 and accuracy of \pm 0.1 . The conductivity and total dissolved solids (TDS) measured utilizing WTW inoLap cond. level 1 instrument (German). The dissolved oxygen was measured by used Lovibond-SensoDirect- Oxi200 instrument (German) the instrument can be measured the temperature with measuring dissolved oxygen.

\subsection{The Experimental Set-Up}

The wastewater source for the present study was a preliminary treated wastewater from Al Qenayat wastewater treatment plant, Zagazig, Egypt. The preliminary treatment works in the mentioned facility includes mechanical cleaning screen, and grit removal chamber. The influent wastewater characteristics were measured. The recorded parameters as total nitrogen, ammonia nitrogen, COD, BOD, pH, conductivity, and temperature, are shown in Tables 2 and 3. The samples were analyzed in accordance with Standard Methods for the Examination of Water and Wastewater; APHA, AWWA and WEF, 21st Edition, 2005 [11].

Table2. The raw wastewater characteristics

\begin{tabular}{|l|c|c|c|c|}
\hline Parameter & Unit & Min & Max & Average \\
\hline TKN & $\mathrm{mg} / \mathrm{l}$ & 28.5 & 81.2 & 51.7 \\
\hline Ammonia - N & $\mathrm{mg} / \mathrm{l}$ & 20.7 & 44.8 & 38 \\
\hline COD & $\mathrm{mg} / \mathrm{l}$ & 390 & 979.2 & 659.4 \\
\hline BOD.5 & $\mathrm{mg} / \mathrm{l}$ & 88.5 & 550.6 & 336.6 \\
\hline Conductivity & $\mu \mathrm{s} / \mathrm{cm}$ & 1353 & 1651 & 1093 \\
\hline $\mathrm{pH}$ & $\ldots$. & 7.4 & 8.9 & 8 \\
\hline Temperature & ${ }^{\circ} \mathrm{C}$ & 14.8 & 29.4 & 21.4 \\
\hline Flow & $\mathrm{m}^{3} / \mathrm{day}$ & 12000 & 16000 & 14000 \\
\hline
\end{tabular}

Table3. The settled wastewater conditions

\begin{tabular}{|l|c|c|c|c|}
\hline Parameter & Unit & Min & Max & Average \\
\hline TKN & $\mathrm{mg} / \mathrm{l}$ & 11.7 & 56.6 & 33.7 \\
\hline Ammonia - N & $\mathrm{mg} / \mathrm{l}$ & 9.5 & 40.3 & 26 \\
\hline COD & $\mathrm{mg} / \mathrm{l}$ & 150 & 540 & 325 \\
\hline BOD.5 & $\mathrm{mg} / \mathrm{l}$ & 9.2 & 89 & 32.6 \\
\hline Conductivity & $\mu \mathrm{s} / \mathrm{cm}$ & 1314 & 1728 & 1465 \\
\hline $\mathrm{pH}$ & $\ldots$. & 7.6 & 8.8 & 8.1 \\
\hline Temperature & ${ }^{\circ} \mathrm{C}$ & 13.9 & 29.6 & 21.3 \\
\hline Flow & $\mathrm{m}^{3} / \mathrm{day}$ & 12000 & 16000 & 14000 \\
\hline
\end{tabular}

\subsection{Samples Collection}

The samples were taken through two points the first point after mechanical cleaning screen, and grit removal chamber and this was the raw wastewater and the second point after the primary settling tank. Sewage in this region significantly affected by animal wastewater and Ruth cattle and this affected of the nitrogen components parameters, and this is illustrated at the measuring of the influent wastewater at Tables 2 and 3, the wastewater plant at Al Qenayat city and surrounding villages Similar to many wastewater plants in Egypt.

The plant screen from the coarse screen type where the channel wide $55 \mathrm{~cm}$, channel depth $115 \mathrm{~cm}$, space between bars $2.5 \mathrm{~cm}$, flow rate (per screen) $556 \mathrm{~m} 3 / \mathrm{h}$, motor power $0.75 \mathrm{~kW}$. And the second stage was the grit removal chamber (or Grit scraper) where channel wide $2 * 100 \mathrm{~cm}$, depth of chamber $130 \mathrm{~cm}$, motor power $1 * 0.18 \mathrm{~kW}$ - driving unit, and $2 * 0.25 \mathrm{~kW}$ - lifting unit.

The settling wastewater samples were taken after the primary sedimentation tanks of Al Qenayat WWTP. there are four primary sedimentation tanks found in the plant. The dimensions of primary sedimentation tank were, Tank diameter $=16 \mathrm{~m}$, Bridge length $=8.8 \mathrm{~m}$, Depth $=2.0 \mathrm{~m}$, Actual volume $=400 \mathrm{~m}^{3}$ and The hydraulic detention time $=2.0$ hours. 


\subsection{Methodology}

The nitrogen components were measured and calculated by used Table 4 and this for the raw samples and settled samples. The procedures used to measure these fractions were based on the standard methods (4500- $\mathrm{NH}_{3}$ Nitrogen (ammonia), 4500-Norg Nitrogen (organic), Standard Methods for the Examination of Water and Wastewater, 2005) [11].

Table4. Methodology of the determination of TKN fractions [12]

\begin{tabular}{|c|c|}
\hline TKN fractions & Methodology of determination \\
\hline $\mathrm{S}_{\mathrm{NH}}-$ soluble ammonia nitrogen & $\mathrm{S}_{\mathrm{NH} \mathrm{MF}}{ }^{*}$ \\
\hline $\begin{array}{l}\mathrm{S}_{\mathrm{ND}} \text { - soluble organic nitrogen, } \\
\text { biologically degradable }\end{array}$ & $\begin{array}{l}\mathrm{S}_{\mathrm{ND}} \cong 0.02 \cdot \mathrm{S}_{\mathrm{S}} \text { according to }[\text { Roeleveld } \text { P.J., } \\
\text { loosdrecht,2002] }\end{array}$ \\
\hline $\begin{array}{l}\mathrm{S}_{\mathrm{NI}} \text { - soluble organic nitrogen, } \\
\text { biologically undegradable }\end{array}$ & $\mathrm{S}_{\mathrm{NI}}=\mathrm{TKN}_{\mathrm{MF}}-\mathrm{S}_{\mathrm{NH}}-\mathrm{S}_{\mathrm{ND}}$ \\
\hline $\begin{array}{l}\mathrm{X}_{\mathrm{ND}} \text { - particulate organic nitrogen, } \\
\text { biologically degradable }\end{array}$ & $\begin{array}{l}\mathrm{X}_{\mathrm{ND}} \cong 0.04 \cdot \mathrm{X}_{\mathrm{S}} \text { according to } \text { [Roeleveld P.J., } \text { Van } \\
\text { loosdrecht,2002] }\end{array}$ \\
\hline $\begin{array}{l}\mathrm{X}_{\mathrm{NI}^{-}} \text {particulate organic nitrogen, } \\
\text { biologically undegradable }\end{array}$ & $\mathrm{X}_{\mathrm{NI}} \cong \mathrm{TKN}_{\mathrm{tot}}-\mathrm{S}_{\mathrm{NH}}-\mathrm{S}_{\mathrm{ND}}-\mathrm{X}_{\mathrm{ND}}$ \\
\hline
\end{tabular}

* $S_{N H} M F$, soluble ammonia nitrogen was determined by filtrated the raw wastewater samples by using $0.45 \mu \mathrm{m}$ membrane filters; obtained the identical values, for non-filtrated samples, the inorganic ammonia nitrogen was presented in wastewater. $T K_{N M F}$, total Kjeldahl nitrogen was determined for filtrated samples by using membrane filters $0.45 \mu \mathrm{m}$. TKN ${ }_{\text {too }}$ the total Kjeldahl nitrogen in raw wastewater samples [12].

\subsection{Analytical Methods}

\subsubsection{Ammonia Nitrogen}

For accurate results, it was generally preferable to distill off ammonia from the sample, and absorb in boric acid. (The code at the Standard Methods for the Examination of Water and Wastewater, 2005 was $4500-\mathrm{NH}_{3} \mathrm{E}$ ).

Distillation apparatus: arrange a borosilicate glass flask of $800 \mathrm{~mL}$ capacity attached to a vertical condenser so that the outlet tip may be submerged below the surface of the receiving acid solution. The $\mathrm{pH}$ was measured utilizing WTW inoLap $\mathrm{pH}$ level 2 instrument, with measuring range from 0 to 14 and accuracy of \pm 0.1 the instrument can measure $\mathrm{pH}$ value and temperature for the sample.

Reagents: Ammonia-free water, Borate buffer solution: Add $88 \mathrm{~mL} 0.1 \mathrm{~N} \mathrm{NaOH}$ solution to $500 \mathrm{~mL}$ approximately $0.025 \mathrm{M}$ sodium tetraborate $\left(\mathrm{Na}_{2} \mathrm{~B}_{4} \mathrm{O}_{7}\right)$ solution $\left(9.5 \mathrm{~g} \mathrm{Na}_{2} \mathrm{~B}_{4} \mathrm{O}_{7} \cdot 10 \mathrm{H}_{2} \mathrm{O} / \mathrm{L}\right)$ and dilute to $1 \mathrm{~L}$, Sodium hydroxide, $6 \mathrm{~N}$, Neutralization agent: Sodium hydroxide $\mathrm{NaOH} 1 \mathrm{~N}$, and Sulfuric acid $\mathrm{H}_{2} \mathrm{SO}_{4} 1 \mathrm{~N}$, Absorbent solution, plain boric acid: Dissolve $20 \mathrm{~g} \mathrm{H}_{3} \mathrm{BO}_{3}$ in water and dilute to $1 \mathrm{~L}$, Indicating boric acid solution: Dissolve $20 \mathrm{~g} \mathrm{H}_{3} \mathrm{BO}_{3}$ in water, add $10 \mathrm{~mL}$ mixed indicator solution, and dilute to $1 \mathrm{~L}$. Prepare monthly, Sulfuric acid, 0.04N: Dilute $1.0 \mathrm{~mL}$ conc $\mathrm{H}_{2} \mathrm{SO}_{4}$ to $1 \mathrm{~L}$, Mixed indicator solution: Dissolve $200 \mathrm{mg}$ methyl red indicator in $100 \mathrm{~mL} \mathrm{95 \%} \mathrm{ethyl} \mathrm{or} \mathrm{isopropyl} \mathrm{alcohol.}$ Dissolve $100 \mathrm{mg}$ methylene blue in $50 \mathrm{~mL} \mathrm{95 \%} \mathrm{ethyl} \mathrm{or} \mathrm{isopropyl} \mathrm{alcohol.} \mathrm{Combine} \mathrm{solutions.}$ Prepared monthly, and Standard sulfuric acid titrant, $0.02 \mathrm{~N}$.

Preparation of equipment: Add $500 \mathrm{~mL}$ water and $20 \mathrm{~mL}$ borate buffer, adjust $\mathrm{pH}$ to 9.5 with $6 \mathrm{~N}$ $\mathrm{NaOH}$ solution, and add to a distillation flask. Add $25 \mathrm{~mL}$ borate buffer solution and adjust to $\mathrm{pH} 9.5$ with $6.0 \mathrm{~N} \mathrm{NaOH}$ using a $\mathrm{pH}$ meter.

\subsubsection{Total Kjeldahl Nitrogen (TKN)}

Total Kjeldahl nitrogen or TKN is the sum of organic nitrogen, ammonia $\left(\mathrm{NH}_{3}\right)$, and ammonium $\left(\mathrm{NH}_{4}{ }^{+}\right)$in the chemical analysis of wastewater, the standard method code was $4500-\mathrm{N}$ org. $\mathrm{B}$.

The method consists of heating a substance with sulfuric acid, which decomposes the organic substance by oxidation to liberate the reduced nitrogen as ammonium sulfate. In this step potassium sulfate was added to increase the boiling point of the medium (from $337^{\circ} \mathrm{C}$ to $373^{\circ} \mathrm{C}$ ). Chemical decomposition of the sample was completed when the initially very dark-colored medium was become clear and colorless. The solution was then distilled with a small quantity of sodium hydroxide, which converts the ammonium salt to ammonia. The amount of ammonia present, and thus the amount of nitrogen present in the sample, was determined by back titration. The end of the condenser was dipped into a solution of boric acid. The ammonia reacts with the acid and the remainder of the acid was then titrated with a sodium carbonate solution by way of a methyl orange $\mathrm{pH}$ indicator. 
Ragaa El Sheikh et al.

Degradation: Sample $+\mathrm{H}_{2} \mathrm{SO}_{4} \rightarrow\left(\mathrm{NH}_{4}\right)_{2} \mathrm{SO}_{4}(\mathrm{aq})+\mathrm{CO}_{2}(\mathrm{~g})+\mathrm{SO}_{2}(\mathrm{~g})+\mathrm{H}_{2} \mathrm{O}(\mathrm{g})$

Liberation of ammonia: $\left(\mathrm{NH}_{4}\right)_{2} \mathrm{SO}_{4}(\mathrm{aq})+2 \mathrm{NaOH} \rightarrow \mathrm{Na}_{2} \mathrm{SO}_{4}(\mathrm{aq})+2 \mathrm{H}_{2} \mathrm{O}(\mathrm{l})+2 \mathrm{NH}_{3}(\mathrm{~g})$

Capture of ammonia: $\quad \mathrm{B}(\mathrm{OH})_{3}+\mathrm{H}_{2} \mathrm{O}+\mathrm{NH}_{3} \rightarrow \mathrm{NH}_{4}{ }^{+}+\mathrm{B}(\mathrm{OH})_{4}{ }^{-}$

Back-titration: $\mathrm{B}(\mathrm{OH})_{3}+\mathrm{H}_{2} \mathrm{O}+\mathrm{Na}_{2} \mathrm{CO}_{3} \rightarrow \mathrm{NaHCO}_{3}(\mathrm{aq})+\mathrm{NaB}(\mathrm{OH})_{4}(\mathrm{aq})+\mathrm{CO}_{2}(\mathrm{~g})+\mathrm{H}_{2} \mathrm{O}$

Nesslerization spectrophotometric method: The measurement of ammonia concentration in wastewaters by Nessler method depend on that the graduated yellow to brown color produced by the Nessler-ammonia reaction was strongly absorbed over a wide range. $(\lambda=400-500 \mathrm{~nm})$. Ammonia produces a yellow color compound when reacts with alkaline Nessler reagent.

The chemical reaction of the method is given below:

$$
2 \mathrm{Kr}_{2} \mathrm{Hgl}_{4}+\mathrm{NH}_{3}+3 \mathrm{KOH} \rightarrow\left(\mathrm{NH}_{2} \mathrm{Hg}_{2} \mathrm{IO}\right)+7 \mathrm{Kl}+2 \mathrm{H}_{2} \mathrm{O}
$$

The ammonia was measured utilizing Thermo Spectronic instrument, with measuring range of 300 to 700nm, (GENESYSTM 20) spectrophotometer was an easy to use instrument that performs absorbance, $\%$ transmittance and concentration measurements with in the wave length range of 325 to 1100 nanometers.

COD was measured according to the standard method $5220 \mathrm{~B}$. In this method, wastewater sample was added to sulfuric acid solution with a known volume of potassium dichromate $\left(\mathrm{K}_{2} \mathrm{Cr}_{2} \mathrm{O}_{7}\right)$. After boiling the mixture for 2 hours at $150^{\circ} \mathrm{C}$ by VELP-ECO instrument, the remaining unreduced $\mathrm{K}_{2} \mathrm{Cr}_{2} \mathrm{O}_{7}$ was titrated with Ferrous Ammonium Sulfate (FAS).

\section{RESULTS AND DISCUSSION}

Two groups of analysis and this is due to the sample source.

\subsection{The first results of raw wastewater}

The results of the various components of the nitrogen was measured at the different conditions as shown in Table 2.

\subsubsection{Total Kjeldahl Nitrogen (TKN)}

Raw wastewater had values of TKN range from 28.56 to $81.2 \mathrm{mg} / \mathrm{l}$ with average value $51.7 \mathrm{mg} / \mathrm{l}$. TKN average $70 \mathrm{mg} / 1$ [16] (Figure 2). Seidl, et al., (1998) proposed that the concentrations of TKN ranged from 28 to $59 \mathrm{mg} / \mathrm{L}$ [17]. Haider and Ali (2010), in their research raw wastewater samples had average value of TKN $41 \mathrm{mg} / \mathrm{l}$ where BOD5 $160 \mathrm{mg} / \mathrm{l}$ [18].

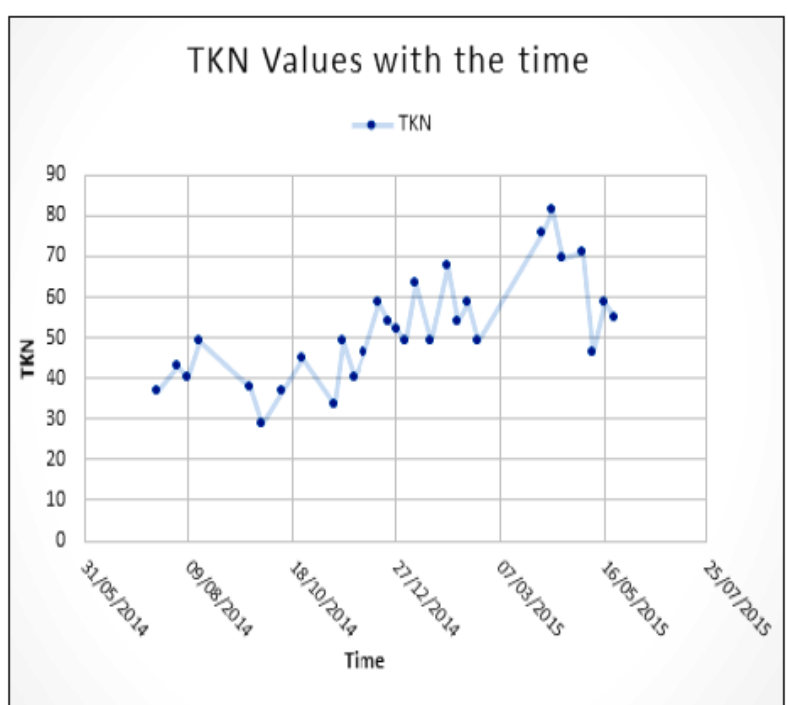

(a)

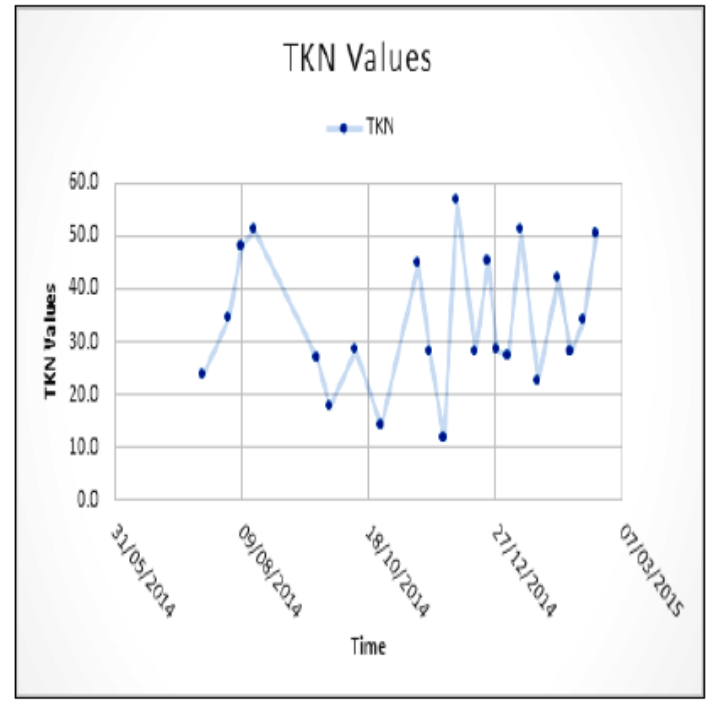

(b)

Figure2. The TKN Values for (a) raw wastewater and (b) settled wastewater virsus the time 


\subsubsection{Free Ammonia Nitrogen, $\mathrm{SNH}$}

This component was the largest value of the nitrogen components. Raw wastewater had values of ammonia nitrogen $\left(\mathrm{S}_{\mathrm{NH}}\right)$ range from 20.7 to $44.8 \mathrm{mg} / \mathrm{l}$ with average value $38 \mathrm{mg} / \mathrm{l}$ and $\left(\mathrm{S}_{\mathrm{NH}} \%\right)$ percent from TKN range from $42.9 \%$ to $76.6 \%$ with average value $73.5 \%$. Zawilski and Brzezińska (2008), ammonia nitrogen $\left(\mathrm{S}_{\mathrm{NH}}\right)$ percent from $\mathrm{TKN}$ range from $53 \%$ to $86 \%$ with average value $66.5 \%$ [12], Seidl et al. (1998) proposed that the concentrations of ammonia ranged from 19 to $35 \mathrm{mg} / \mathrm{L}$ [17]. Haider and Ali (2010), found that raw wastewater had average value of ammonia $\left(\mathrm{NH}_{3}\right) 26.8 \mathrm{mg} / \mathrm{l}$ where $\mathrm{BOD}_{5} 160 \mathrm{mg} / \mathrm{l}[18]$.

\subsubsection{Organically Bound TKN}

Raw wastewater had values of organically bound nitrogen range from 7.8 to $36.4 \mathrm{mg} / \mathrm{l}$ with average value $13.7 \mathrm{mg} / \mathrm{l}$. The values of raw wastewater organically bound nitrogen percent from TKN range from $23.4 \%$ to $57.1 \%$ with average value $26.5 \%$. Rössle and Pretorius (2001), found that the values of raw wastewater organically bound TKN percent from TKN with average value $25 \%$ [14].

\subsubsection{Organic Nitrogen Soluble}

Raw wastewater had values of organic nitrogen soluble range from 2.8 to $16.8 \mathrm{mg} / \mathrm{l}$ with average value $6.05 \mathrm{mg} / \mathrm{l}$. The values of raw wastewater organic nitrogen soluble percent from TKN range from $6.8 \%$ to $30.6 \%$ with average value $11.7 \%$. Rössle and Pretorius (2001), found that the values of raw wastewater Organic Nitrogen soluble percent from TKN with average value $9 \%$ [14].

\subsubsection{Organic Nitrogen Particulate}

Raw wastewater had values of organic nitrogen particulate range from 4.48 to $27.44 \mathrm{mg} / \mathrm{l}$ with average value $7.65 \mathrm{mg} / \mathrm{l}$. The values of raw wastewater organic nitrogen particulate percent from TKN range from $11.9 \%$ to $46.7 \%$ with average value $14.8 \%$. Rössle and Pretorius (2001), found that the values of raw wastewater Organic Nitrogen particulate percent from TKN with average value 16 $\%$ [14].

\subsubsection{Soluble Organic Nitrogen Biologically Degradable, $S_{N D}$}

Raw wastewater had values of soluble biodegradable organic nitrogen $\left(\mathrm{S}_{\mathrm{ND}}\right)$ range from 0.56 to 14.28 $\mathrm{mg} / \mathrm{l}$ with average value $4.3 \mathrm{mg} / \mathrm{l}$. The values of raw wastewater soluble biodegradable organic nitrogen $\left(\mathrm{S}_{\mathrm{ND}}\right)$ percent from TKN range from $0.8 \%$ to $26 \%$ with average value $8.3 \%$. Zawilski and Brzezińska (2008), found that the value wastewater soluble organic nitrogen biologically degradable $\left(\mathrm{S}_{\mathrm{ND}}\right)$ percent from TKN range from $5.0 \%$ to $7.0 \%$ with average value $5.8 \%$ [12]. WH Rössle and Pretorius (2001), found that the values of raw wastewater soluble organic nitrogen biologically degradable $\left(\mathrm{S}_{\mathrm{ND}}\right)$ percent from TKN with average value $6 \%$ [14].

\subsubsection{Soluble Organic Nitrogen Biologically Undegradable, $S_{N I}$}

Raw wastewater had values of soluble organic nitrogen biologically undegradable $\left(\mathrm{S}_{\mathrm{NI}}\right)$ range from 0.78 to $8.4 \mathrm{mg} / \mathrm{l}$ with average value $1.75 \mathrm{mg} / \mathrm{l}$. The values of raw wastewater soluble organic nitrogen biologically undegradable $\left(\mathrm{S}_{\mathrm{NI}}\right)$ percent from $\mathrm{TKN}$ range from $1.6 \%$ to $12.1 \%$ with average value 3.4 $\%$.

Zawilski and Brzezińska (2008), found that the value wastewater Soluble organic nitrogen biologically undegradable $\left(\mathrm{S}_{\mathrm{NI}}\right)$ percent from TKN range from $2 \%$ to $18 \%$ with average value $8.4 \%$ [12]. Rössle and Pretorius (2001), found that the values of raw wastewater Soluble organic nitrogen unbiologically degradable $\left(\mathrm{S}_{\mathrm{NI}}\right)$ percent from TKN with average value $3 \%$ [14].

\subsubsection{Particulate Organic Nitrogen Biologically Degradable, $X_{N D}$}

Raw wastewater had values of Particulate organic nitrogen biologically degradable $\left(\mathrm{X}_{\mathrm{ND}}\right)$ range from 4 to $4.8 \mathrm{mg} / \mathrm{l}$ with average value $3.2 \mathrm{mg} / \mathrm{l}$. The values of raw wastewater Particulate organic nitrogen biologically degradable $\left(\mathrm{X}_{\mathrm{ND}}\right)$ percent from $\mathrm{TKN}$ range from $4.9 \%$ to $8.6 \%$ with average value 6.2 $\%$.

Zawilski and Brzezińska (2008), found that the value wastewater Particulate organic nitrogen biologically degradable $\left(\mathrm{X}_{\mathrm{ND}}\right)$ percent from TKN range from $2 \%$ to $24 \%$ with average value $12.5 \%$ [12]. Rössle and Pretorius (2001), found that the values of raw wastewater particulate organic nitrogen biologically degradable $\left(\mathrm{X}_{\mathrm{ND}}\right)$ percent from $\mathrm{TKN}$ with average value $6 \%$ [14]. 


\subsubsection{Particulate Organic Nitrogen Biologically Undegradable, $X_{N I}$}

Raw wastewater had values of Particulate organic nitrogen biologically undegradable $\left(\mathrm{X}_{\mathrm{NI}}\right)$ range from 0.38 to $11.59 \mathrm{mg} / \mathrm{l}$ with average value $4.45 \mathrm{mg} / \mathrm{l}$. The values of raw wastewater Particulate organic nitrogen biologically undegradable $\left(\mathrm{X}_{\mathrm{NI}}\right)$ percent from $\mathrm{TKN}$ range from $1 \%$ to $17.1 \%$ with average value $8.6 \%$.

Zawilski and Brzezińska (2008), found that the value wastewater Particulate organic nitrogen biologically undegradable $\left(\mathrm{X}_{\mathrm{NI}}\right)$ percent from TKN range from $1 \%$ to $18 \%$ with average value $6.8 \%$ [12]. Rössle and Pretorius (2001), found that the values of raw wastewater Particulate organic nitrogen biologically undegradable $\left(\mathrm{X}_{\mathrm{NI}}\right)$ percent from $\mathrm{TKN}$ with average value $10 \%$ [14].

\subsection{The Second Results of Settled Wastewater}

The following parameter were determined at the following condition appered at the Table 3.

\subsubsection{Total Kjeldahl Nitrogen (TKN)}

Settled wastewater had values of TKN range from 11.7 to $56.6 \mathrm{mg} / \mathrm{l}$ with average value $33.7 \mathrm{mg} / \mathrm{l}$. Haider and Ali (2010), in their research the settled wastewater had average value of TKN $36 \mathrm{mg} / \mathrm{l}$ where $\mathrm{BOD}_{5} 131 \mathrm{mg} / \mathrm{l}[18]$.

\subsubsection{Free Ammonia Nitrogen, $S_{N H}$}

Settled wastewater had values of ammonia nitrogen $\left(\mathrm{S}_{\mathrm{NH}}\right)$ range from 9.5 to $40.3 \mathrm{mg} / \mathrm{l}$ with average value $26.0 \mathrm{mg} / \mathrm{l}$. The values of settled wastewater ammonia nitrogen $\left(\mathrm{S}_{\mathrm{NH}}\right)$ percent from TKN range from $59 \%$ to $84 \%$ with average value $77.2 \%$ (Figure 2). Haider and Ali (2010), in their research the settled wastewater had average value of ammonia $\left(\mathrm{NH}_{3}\right) 21.2 \mathrm{mg} / \mathrm{l}$ where $\mathrm{BOD}_{5} 131 \mathrm{mg} / \mathrm{l}$ [18]. Rössle and Pretorius (2001), found that the values of settled wastewater ammonia nitrogen $\left(\mathrm{S}_{\mathrm{NH}}\right)$ percent from TKN with average value $83 \%$ [14].

\subsubsection{Organically Bound TKN}

Settled wastewater had values of organically bound nitrogen range from 2.2 to $20.2 \mathrm{mg} / \mathrm{l}$ with average value $7.7 \mathrm{mg} / 1$. The values of settled wastewater organically bound nitrogen percent from TKN range from $16 \%$ to $41 \%$ with average value $22.8 \%$. Rössle and Pretorius (2001), found that the values of settled wastewater Organically bound TKN \% from TKN with average value $17 \%$ [14].

\subsubsection{Organic Nitrogen Soluble}

Settled wastewater had values of organic nitrogen soluble range from 1.4 to $14.6 \mathrm{mg} / \mathrm{l}$ with average value $4.15 \mathrm{mg} / \mathrm{l}$. The values of settled wastewater organic nitrogen soluble percent from TKN range from $9.4 \%$ to $28.9 \%$ with average value $12.3 \%$. Rössle and Pretorius (2001), found that the values of settled wastewater Organic Nitrogen soluble percent from TKN with average value $10.5 \%$ [14].

\subsubsection{Organic Nitrogen Particulate}

Settled wastewater had values of organic nitrogen particulate range from 0.8 to $12.9 \mathrm{mg} / \mathrm{l}$ with average value $3.55 \mathrm{mg} / \mathrm{l}$. The values of settled wastewater organic nitrogen particulate percent from TKN range from $6.1 \%$ to $24.2 \%$ with average value $10.5 \%$. Rössle and Pretorius (2001), found that the values of settled wastewater Organic Nitrogen particulate percent from TKN with average value $6.5 \%$ [14].

\subsubsection{Soluble Organic Nitrogen Biologically Degradable, $S_{N D}$}

Settled wastewater had values of soluble biodegradable organic nitrogen $\left(\mathrm{S}_{\mathrm{ND}}\right)$ range from 0.8 to 13 $\mathrm{mg} / \mathrm{l}$ with average value $2.86 \mathrm{mg} / \mathrm{l}$. The values of settled wastewater soluble biodegradable organic nitrogen $\left(\mathrm{S}_{\mathrm{ND}}\right)$ percent from TKN range from $5.2 \%$ to $25.7 \%$ with average value $8.5 \%$. Rössle and Pretorius (2001), found that the values of settled wastewater Soluble organic nitrogen biologically degradable $\left(\mathrm{S}_{\mathrm{ND}}\right)$ percent from $\mathrm{TKN}$ with average value $6.5 \%$ [14].

\subsubsection{Soluble Organic Nitrogen Biologically Undegradable, $S_{N I}$}

Settled wastewater had values of soluble organic nitrogen biologically undegradable $\left(\mathrm{S}_{\mathrm{NI}}\right)$ range from 0.5 to $2.3 \mathrm{mg} / \mathrm{l}$ with average value $1.29 \mathrm{mg} / \mathrm{l}$. The values of settled wastewater soluble organic nitrogen biologically undegradable $\left(\mathrm{S}_{\mathrm{NI}}\right)$ percent from $\mathrm{TKN}$ range from $2.6 \%$ to $4.6 \%$ with average 
value $3.8 \%$. Rössle and Pretorius (2001), found that the values of settled wastewater Soluble organic nitrogen unbiologically degradable $\left(\mathrm{S}_{\mathrm{NI}}\right)$ percent from $\mathrm{TKN}$ with average value $4 \%$ [14].

\subsubsection{Particulate Organic Nitrogen Biologically Degradable, $X_{N D}$}

Settled wastewater had values of Particulate organic nitrogen biologically degradable $\left(\mathrm{X}_{\mathrm{ND}}\right)$ range from 0.8 to $3.3 \mathrm{mg} / \mathrm{l}$ with average value $2.15 \mathrm{mg} / \mathrm{l}$. The values of settled wastewater Particulate organic nitrogen biologically degradable $\left(\mathrm{X}_{\mathrm{ND}}\right)$ percent from TKN range from $4.9 \%$ to $8.1 \%$ with average value $6.4 \%$. Rössle and Pretorius (2001), found that the values of settled wastewater Particulate organic nitrogen biologically degradable $\left(\mathrm{X}_{\mathrm{ND}}\right)$ percent from $\mathrm{TKN}$ with average value 6.5 $\%[14]$.

\subsubsection{Particulate Organic Nitrogen Biologically Undegradable, $X_{N I}$}

Settled wastewater had values of Particulate organic nitrogen biologically undegradable $\left(\mathrm{X}_{\mathrm{NI}}\right)$ range from 0.0 to $9.6 \mathrm{mg} / \mathrm{l}$ with average value $1.4 \mathrm{mg} / \mathrm{l}$. The values of settled wastewater Particulate organic nitrogen biologically undegradable $\left(\mathrm{X}_{\mathrm{NI}}\right)$ percent from $\mathrm{TKN}$ range from $0.0 \%$ to $17.8 \%$ with average value $4.1 \%$. Rössle and Pretorius (2001), found that the values of settled wastewater Particulate organic nitrogen biologically undegradable $\left(\mathrm{X}_{\mathrm{NI}}\right)$ percent from TKN with average value $0.0 \%$ [14].

Table 5 summarize percentage contribution of particular TKN fractions (ammonia nitrogen $\mathrm{S}_{\mathrm{NH}}$, $\mathrm{S}_{\mathrm{ND}}$, $\mathrm{S}_{\mathrm{NI}}, \mathrm{X}_{\mathrm{NI}}$ and $\mathrm{X}_{\mathrm{ND}}$ ) of raw and selling wastewater.

Table5. Percentage contribution of particular TKN fractions of raw and settled wastewater

\begin{tabular}{|c|c|c|c|c|c|c|c|c|c|c|}
\hline \multirow{2}{*}{$\begin{array}{l}\text { TKN } \\
\text { fractions }\end{array}$} & \multicolumn{2}{|c|}{$\mathbf{S}_{\mathrm{NH}}$} & \multicolumn{2}{|c|}{$\mathbf{S}_{\mathrm{ND}}$} & \multicolumn{2}{|c|}{$\mathbf{S}_{\mathrm{NI}}$} & \multicolumn{2}{|c|}{$\mathbf{X}_{\mathrm{NI}}$} & \multicolumn{2}{|c|}{$\mathbf{X}_{\mathrm{ND}}$} \\
\hline & $\begin{array}{l}\text { Range* } \\
\%\end{array}$ & $\begin{array}{l}\text { Mean** } \\
\%\end{array}$ & $\begin{array}{l}\text { Range* } \\
\%\end{array}$ & $\begin{array}{l}\text { Mean** } \\
\%\end{array}$ & $\begin{array}{l}\text { Range* } \\
\%\end{array}$ & $\begin{array}{l}\text { Mean** } \\
\%\end{array}$ & $\begin{array}{l}\text { Range* } \\
\%\end{array}$ & $\begin{array}{l}\text { Mean** } \\
\%\end{array}$ & $\begin{array}{l}\text { Range* } \\
\%\end{array}$ & $\begin{array}{l}\text { Mean** } \\
\%\end{array}$ \\
\hline \begin{tabular}{|l|} 
Raw \\
wastewater
\end{tabular} & $42.9-76.6$ & 73.5 & $0.8-26$ & 8.3 & $1.6-12.1$ & 3.4 & $1-17.1$ & 8.6 & $4.9-8.6$ & 6.2 \\
\hline \begin{tabular}{|l|} 
Settled \\
wastewater
\end{tabular} & $58-84$ & 77.2 & $\begin{array}{l}5.2- \\
25.7\end{array}$ & 8.5 & $2.6-4.6$ & 3.8 & $0-17.8$ & 4.1 & $4.9-8.1$ & 6.4 \\
\hline
\end{tabular}

* the range for instantaneous samples

** mean values for composite samples weighted by flow

\section{Conclusion}

Knowledge of the participation of particular TKN fractions enables more exact estimation of the biological degradablity of wastewater contaminations than the generally applied TKN/BOD 5 ratio. The presented analysis of fractional composition of TKN for raw and settled wastewater proves distinct differences between these samples. A significant increase of the particulate fraction of TKN in raw wastewater samples was observed. The comparison between the measured results and the default values used in literature was achieved successfully. And Derivation of the interrelationships between the measured nitrogen components. Raw wastewater nitrogen components percent from the TKN was determined as, $\mathrm{S}_{\mathrm{NH}} \%$ was $73.5 \%, \mathrm{~S}_{\mathrm{ND}} \%$ was $8.3 \%, \mathrm{~S}_{\mathrm{NI}} \%$ was $3.4 \%, \mathrm{X}_{\mathrm{ND}} \%$ was $6.2 \%$, and $\mathrm{X}_{\mathrm{NI}} \%$ was $8.6 \%$. Settled wastewater nitrogen components percent from the TKN was determined as, $\mathrm{S}_{\mathrm{NH}} \%$ was $77.2 \%, \mathrm{~S}_{\mathrm{ND}} \%$ was $8.5 \%, \mathrm{~S}_{\mathrm{NI}} \%$ was $3.8 \%, \mathrm{X}_{\mathrm{ND}} \%$ was $6.4 \%, \mathrm{X}_{\mathrm{NI}} \%$ was $4.1 \%$.

\section{ACKNOWLEDGMENT}

All thanks and gratitude to the Holding Company of Water and wastewater (HCWW), Egypt.

\section{REFERENCES}

[1] Kujawa-Roeleveld K., Estimation of denitrification potential with respiration based techniques, Thesis Wageningen University, ISBN 90-5808-228-8 (2000).

[2] Pasztor I., Thury P. and Pulai J., Chemical oxygen demand fractions of municipal wastewater for modeling of wastewater treatment, Int. J. Environ. Sci. Tech., 6 51-56 (2009).

[3] Roeleveld P. and Van Loosdrecht M., Experience with guidelines for wastewater characterisation in The Netherlands, Water Sci. Technol., 45, 77-87 (2002).

[4] Tchobanoglous G. and Burton F.L., Wastewater Engineering: Treatment, Disposal and Reuse ( $3^{\text {rd }}$ edn.) Metcalf and Eddy Inc., McGraw-Hill, New York, USA, (1991). 
[5] Park J.K., Wang J. and Novotny G., Wastewater Characterisation for Evaluation of Biological Phosphorus Removal: Wastewater Fractionation. WDNR Research Report 174, Wisconsin Dept. of Natural Resources, Wisconsin-Madison, USA, (1997) (www.dnr.state.wi.us).

[6] Pehlivanoglu-Mantas E. and Sedlak D.L., Wastewater-derived dissolved organic nitrogen: analytical methods, characterization, and effects-A review, Crit. Rev. Environ. Sci. Technol., 36, 261-285 (2006).

[7] Tzollas N. M., Zachariadis G.A., Anthemidis A. N. and Stratis J. A., A new approach to indophenol blue method for determination of ammonium in geothermal waters with high mineral content. Intern. J. Environ. Anal. Chem. 90, 115-126 (2010).

[8] Jeppsson U., Modeling aspects of wastewater treatment processes. Lund Institute of Technology, Sweden, (1996), ISBN 91-88934-00-4.

[9] Henze M., Gujer W., Mino T. and van Loosdrecht M.C.M., Activated Sludge Models ASM1, ASM2, ASM2d and ASM3. Scientific and Technical Report No. 9., TWA Publishing, London, UK, (2000) 16-22.

[10] Butler D., Friedler E., and Gatt K., Characterising the quantity and quality of domestic wastewater inflows, Water Sci. Technol., 31, 13-24 (1995).

[11] American Public Health Association (APHA), American Water Works Association (AWWA) \& Water Environment Federation (WEF): Standard Methods for the Examination of Water and Wastewater, $21^{\text {st }}$ Edition, (2005)

[12] Zawilski M. and Brzezińska A., Variability of COD and TKN Fractions of Combined Wastewater, Polish J. of Environ. Stud., 18, 501-505 (2009).

[13] Szetela R.W., Dynamic model of activated sludge wastewater treatment plant. Prace Naukowe Instytutu Inżynierii Ochrony Środowiska Politechniki Wrocławskiej. 64, 32, Wrocław, (1990) [In Polish].

[14] Rossle W.H. and Pretorius W.A., A review of characterization for on-line prefermenters. Paper 1: Wastewater characterisation., Water S.A., 27, 405 (2001).

[15] Beck C., LE ROY K., SADOWSKI A.G. A coupled sewer system and WWTP modelling approach to minimise annual discharge: a case study. Proc. of the $10^{\text {th }}$ International Conference on Urban Drainage, Copenhagen/Denmark, 21- 26 August 2005. a CD-ROM edition, (2005).

[16] Feng H., Hu L., Mahmood Q., Qiu C., Fang C., Shen D., Anaerobic domestic wastewater treatment with bamboo carrier anaerobic baffled reactor, Intern Biodeterior Biodegrad, 62, 232238 (2008).

[17] Seidl M., Servais P., Martaud M., Gandouin C. and Mouchel J. M. Organic carbon biodegradability and heterotrophic bacteria along a combined sewer catchment during rain events, Water Sci. Technol, 37, 25-33, (1998).

[18] Haider H. and Ali W., Effect of Wastewater Treatment on Bio-kinetics of Dissolved Oxygen in River Ravi, Pak. J. Engg. \& Appl. Sci., 6, 42-51, (2010). 